\title{
MOTIF SOSIAL DAN KEBERMAKNAAN HIDUP REMAJA PAGARALAM
}

\author{
Neneng Anggriany \\ Rika Annisa Yogyakarta
}

\begin{abstract}
This research conducted b find out the infuence of social motive and meaning live at adolescence in Pagaralam. Proposed hypothesis was there is positive correlation between social motive (achievement motive, affiliation motive and power motive) and meaning live of Pagaralam's adolescence.

This research using social motive scale and tive meaning scale. Subjects were 171 adolescence of 15-18 years od, and living in Pagaralam. The sampling technique of this research was purposive sampling.

Data analyzed by regression analysis. The result had proved that ( 1 ) the achievement motive, affiliation motive and power motive have influence to meaning live significantly ( $F=29,983$ with $p \quad 0,00, R=0,592$ and $R 2=0,350$ ) , (2) As predictors, achievement motive, affiliation motive and power motive donate $35 \%$ (3) achievement motive has positive in influencing meaning live significantly $(B=1,727$ with $p 0<0,00)$, (4) affiliation motive has positive $n$ influencing live meaning significantly $(B=0,786$ with $p 0<0,00)$, (5) power motive has negative infuence to meaning live significantly $(B=0,495$ with $p 0<0,00)$.
\end{abstract}

Keywords: Achievement Motive, Affiliation Motive, Power Motive, Live Meaning

\section{Pengantar}

Di antara berbagai kemajuan masyarakat modem sekarang ini, terdapat banyak pula keprihatinan yang menyertai. Salah satunya terkalt dengan dunia remaja, Lembar-lembar berita di koran, televisi ataupun berbagai media semakin marak memberitakan tingkah laku remaja yang semakin menimbulkan keprihatinan. Sebut saja perilaku seks bebas, narkoba, tawuran, bunuh diri, dan gaya hidup kian konsumtif serta hedonis. Melalui media massa dan fasilitas kemoderenan, remaja semakin terkondisikan mengikuti gaya hidup konsumtif yang menuju pada arah destruktif. Perubahan gaya hldup tersebut kian mengkhawatíkan ketika mereka mengidentifikasikan diri dan kehilangan kesejatian diri akibat mentalitas meniru gaya hidup bentukan media. Tidak mengherankan kalau kemudian banyak kasus kematian gadis remaja yang meninggal akibat mengkonsumsi obat pelangsing atau karena operasi plastik memperbesar payudara.

Perilaku seks bebas pun semakin marak. Menurut penelitian Pilar-PKBI Jawa Tengah, tahun 2002 terhadap 64 remaja laki-laki dan 63 perempuan di kota Malang menunjukkan bahwa $20,4 \%$ telah melakukan hubungan seksual. Angka penderita HIV/AIDS pun semakin menanjak. Sekitar $50 \%$ di antaranya terjadi pada kelompok usia 15-29 tahun (Wijaya, 2002)

Frankl (2003), seorang psikoterapis eksistensialis, menyatakan kasus bunuh diri, meluasnya fenomena arkoholisme, seks bebas, pemujaan berlebihan pada uang dan keduniawian, keinginan berlebihan pada kekuasaan, kejahatan, sikap masa bodoh terhadap hidup, pesimis terhadap masa depan adalah bentuk-bentuk dari 
kevakuman eksistensi atau frustrasi eksistensial. Frustrasi yang berkaitan dengan keterhambatan atau kegagalan individu dalam memenuhi keinginan akan makna.

Kondisi tersebut tidak hanya melanda kota-kota metropolis, bahkan merambah puia pada kota-kota kecil. Termasuk d antaranya di kota Pagaralam. Kota kecil yang berpenduduk 119.759 jwa (BPS Pagaralam, 2003) dan menjadikan pertanian serta perkebunan sebagai mata pencaharian utama penduduknya ini, tidak luput dari gejala-gejaia tersebut.

Pagaralam merupakan kota yang terletak di wilayah propinsi Sumatera Selatan. Selain dikenal dengan makanan khas pempek dan berbagai kekayaan tambang, propinsi ini juga dikenal sebagal daerah rawan dan potensial terjadi tindak kriminal, bahkan pada tahun 2003 sempat menduduki posisi lima besar nasional (Sriwijaya Post, 31/12/2004). Menurut Frankl (Koeswara, 1992), kejahatan atau tindak kriminal merupakan salah satu bentuk dari neurosis noogenic, yakni neurosis yang disebabkan ketidakmampuan dalam memenuhi makna dalam hidup. Merujuk pada teori behavioristik bahwa perilaku seseorang akan sangat dipengaruhi oleh lingkungannya, maka data íni dapat menjadi petunjuk adanya kondisi lingkungan yang dapat menjadi pengaruh buruk bagi pertumbuhan remaja, khususnya kebermaknaan hidup mereka.

Kondisi ini mengakibatkan banyak pula remaja yang melakukan tindak kriminal. Salah satunya terlihat dari pembunuhan yang dilakukan tiga orang remaja Sumatera Selatan, yang berusia antara 16-17 tahun terhadap seorang temannya yang berusia 18 tahun hanya karena merasa tersinggung disebutbanci (Sriwijaya Pos, 1/4/2005).

Gejala menyalahgunakan kebebasan juga semakin terlihat. Sumatera Selatan pada tahun 2000, oleh Direktorat Jendral PPM dan PLP Depkes RI ditetapkan sebagai propinsi terbesar ketujuh jumlah penderita HIV/AIDS (Depkes, 2000) di Indonesia. Disebutkan pula bahwa sebagian besar para penderita HIVIAIDS tersebut adalah remaja.

Hasil wawancara penulis dengan enam orang remaja Pagaralam, juga menunjukkan mulai maraknya perilaku seksual bebas. Wawancara pada bulan Juni 2005 terhadap Mawar, Badu, Putra, Asti, Rian, Rini (bukan nama sebenamya), mendapatkan data, satu di antaranya sudah terbiasa bercumbu dalam bentuk perilaku seks sekwilda (sekitar wilayah dada) dengan pacar, dan satu orang sudah melakukan senggama.

Ketika keenam remaja tersebut dihadapkan pada pertanyaan tentang apa tujuan hidup, kebanyakan mereka menginginkan hidup yang bahagia, yakni dengan memiliki banyak uang, memiliki istri cantik atau suami tampan, kaya raya, yang kesemuanya iebih berpusat pada kebahagiaan material.

Menurut Frankl (Koeswara, 1992), ketika seseorang menjadikan diri sebagai pusat dan kebahagiaan materi sebagai tujuan hidup, maka kebermaknaan hidup dan kebahagiaan hakiki akan sulit didapatkan. Dikemukakan pula oleh Madjid (Bastaman. 1996) bahwa tekanan yang berlebihan pada segl materiai kehidupan, akan mengakibatkan hilangnya kesadaran akan makna hidupyang mendalam.

Realitas tersebut bila dicermati menunjukkan adanya masalah pada eksistensi remaja sebagai pribadi yang mempunyai tanggung jawab dan tugas dalam kehidupan ini. Semakin banyak perilaku remaja yang menunjukkan frustrasi eksistensial, akan semakin sulit bagi mereka memenuhi tugas-tugas perkembangan untuk menghadapi masa dewasa dengan baik. Di sisi lain, dengan kondisi tersebut, akan sulit pula bagi remaja menjadi sumber daya manusia yang potensial sebagai penerus keberlangsungan bangsa. Padahal di pundak mereka nasib bangsa ini dipertaruhkan. Oleh karena itu menjadi penting mengangkat topik mengenai kebermaknaan hidup remaja. Terieblh, berbagai penelitian pslkologis telah menunjukkan pentingnya kebermaknaan hidup sebagai faktor yang berpengaruh kuat bagi kesehatan fisik, kepercayaan dri, subjective well being dan kesehatan mental (Setlyartomo, 2004). Frankl (2003) mengungkapkan bahwa 
kebermaknaan hidup sebagai keadaan yang menunjukkan sejauh mana seseorang teleh mengalami dan menghayati kepentingan keberadaan hidupnya menurut sudut pandang dirinya sendiri. Kebermaknaan hidup mulai muncul ketika individu memuiai pematangan spiritual, yaitu pada masa pubertas. Apabila motivasi hidup bermakna ini terpenuhi, maka individu akan merasakan kehidupan yang bermakna. Sebaliknya, bila hasrat hidup bermakna ini tidak dapat terpenuhi, maka individu akan mengalami kehidupan tanpa makna.

\section{Dasar Teori}

Kebermaknaan hidup remaja dipengaruhi oleh motif-motif sosial yang ada dalam diri remaja. Berikut ini akan dijelaskan kebermaknaan hidup, motif sosial, dan pengaruh motif sosial terhadap kebermaknaan hidup.

\section{Kebermaknaan Hidup Remaja}

Frankl mengungkapkan bahwa kebermaknaan hidup adalah keadaan yang menunjukkan sejauh mana seseorang telah mengalami dan menghayati kepentingan keberadaan hidupnya menurut sudut pandang dirinya sendiri (Franki, 2003). Dittman-Kohli dan Westerhof (Hanik, 2004) berpendapat bahwa di dalam term kebermaknaan terdapat dua arti dasar. Pertame, kebermaknaan lebih menunjuk pada interpretasi terhadap pengalaman atau hidup pada umumnya. Kedua, kebermaknaan lebih menunjuk pada tujuantujuan dan motivasi-motivasi yang membuat individu memiliki respek terhadap pengalamannya atau hidupnya.

Menurut Ancok (Franki, 2003) kebermaknean hidup adalah sebuah kekuatan hidup manusia untuk memiliki sebuah komitmen kehidupan. Makna hidup ini bermula dari adanya sebuah visi kehidupan, harapan dalam hidup, đan adanya alasan mengapa seseorang harus tetap hidup. Kebermaknaan hidup dapat diwujudkan dalam sebuah keinginan menjadi orang yang berguna untukorang iain, apakah itu anak, istri, keluarga dekat, komunitas negara dan bahkan umat manusia.

Berdasarkan dari beberapa pengertian kebermaknaan hidup di atas depat diambil kesimpuian bahwa kebermaknaan hidup remaja dalam penelitian Ini adalah penghayatan remaja mengenai kualitas, tujuan dan harapan dalam hidupnya agar dapat berarti bagi diri sendiri dan sesama.

Kebermaknaan hidup akan dimiliki seseorang jika dia dapat mengetahui apa makna dan tujuan hidupnya. Menurut Franki (2003) makna hidup muncul ketika individu memulai pematangan spiritual, yaitu pada masa pubertas. Bastaman (1996), menyebutkan bahwa makna hidup adalah hal-hal yang oleh seseorang dipandang penting, dirasakan berharga dan diyakini sebagai suatu yang benar serta dapat dijadikan tujuan hidupnya.

Makna hidup, mempunyai beberapa karakteristik (Bastaman, 1996). Pertama, makna hidup bersifat subjektif, unik dan personal. Dalam hal ini makna hidup seseorang dan apa yang bermakna baginya biasanya bersifat khusus, berbeda dengan orang iain, dan dari waktu ke waktu dapat berubah. Kedua, makna hidup bersifat spesifik dan konkrit, artinya dapat ditemukan dalam keseharian. Misalnya mengagumi keindahan mentari pagi, muncul perasaan haru dan kasih pada saat memandang bayi mungil, bersemangat dan tulus dalam menger jakan tugas sehari-hari, dan iain-lain. Karakteristik lainnya makna hidup memberi pedoman dan arah terhadap kegiatankegiatan yang dilakukan sehingga makna hidup menantang (challenging) dan mengundang (inviting) seseorang untuk memenuhinya.

Di samping makna hidup yang sifatnya personai, spesifik, makna hidup juga dapat bersifat mutiak (absolut), semesta (universai). Bagi kalangen yang kurang menghargai nilai-nilai keagamaan, alam semesta, pandangan fisafat dan ideologi tertentu dianggap memiliki nilai universal dan dijadikan sumber makna hidupnya. Bagi kalangan yang menjunjung tinggi nilai-niiai keagamaan, maka ketuhanan dan agama merupakan sumber makna hldupnya (Bastaman, 1996). 
Makna hidup seseorang akan berbeda dengan makna hidup orang lain, bahkan berbeda dari satu peristiwa dengan peristiwa yang lain. Walaupun demikian, manusia memiliki kemampuan untuk menemukan kebermaknaan hidupnya dalam keadaan apapun, bahkan ketika harus menghadapi kondisi yang sungguh-sungguh tidak menyenangkan bagi individu tersebut.

Pencarian makna hidup dapat merupakan tugas yang membingungkan dan menantang bagi individu. Namun, hal tersebut merupakan prasyarat bagi perkembangan kepribadian indlvidu. Menurut Frankl (Schultz, 1991) suatu kepribadian yang sehat akan mengandung tingkat ketegangan tertentu, antara apa yang ingin dicapai atau yang ingin diselesaikan dengan apa yang telah dicapai atau yang telah diselesaikan. Adanya ketegangan ini akan mengakibatkan individu yang sehat untuk selalu memperjuangkan tujuan yang dapat memberi makna hidup. Perjuangan yang terus menerus ini akan menghasilkan kehidupan yang penuh semangat dan gembira.

Berbicara tentang kebermaknaan hidup, seringkali selalu dikaitkan dengan hal-hai yang serba rumit, filosofis dan idiologis. Mengaitkannya dengan dunia remaja, seakan merupakan sesuatu hal yang tidak mungkin. Terlalu jauh dan tidak ada hubungannya sama sekali. Namun demikian, Bastaman (1996) menyatakan bahwa makna hidup tidak seialu berkaitan dengan hal-hai rumit dan sulit. Makna hidup juga terkait dengan hal-hal sederhana, mudah dan ada dalam keseharian siapapun juga.

Oieh karena itu, remaja yang dianggap belum saatnya memikirkan hal-hal yang abstrak, filosofis, menjadi mungkin untuk memahami, menghayati dan menjalani kebermaknaan hidup. Apalagl perkembangan kognitif remaja sudah mencapai tahap formal operasional (Santrock, 2003). Tahap perkembangan moral mereka pun sudah mulai mengembangkan moralitas internal. Dengan tahapan perkembangan tersebut, tentunya remaja sudah dapat memahami sejauh mana telah mengalami dan menghayatl kepentingan keberadaan hidupnya menurut sudut pandang dirinya sendiri. Sejauh mana remaja dapat menghayati mengenai kualitas, tujuan dan harapan dalam hidupnya agar dapat berarti bagi diri sendiri dan sesama.

Menurut Frankl (Bastaman, 1996) terdapat tiga komponen kebermaknaan hidup, dimana satu dan lainnya mempunyai hubungan yang erat dan saling mempengaruhi. Ketiga komponen itu adalah: (1) Kebebasan berkehendak (fregdom of wili). Kebebasan berkehendak adalah kebebasan yang dimillki oleh seseorang untuk menentukan sikap dalam hidupnya, menentukan apa yang dianggap penting dan baik bagi dirinya. Kebebasan dalam hal ini bukanlah kebebasan yang mutlak dan tanpa batas, namun kebebasan yang diimbangi sikap tanggung jawab agar tidak berkembang menjadi kesewenangan. (2) Kehendak hidup bermakna (will to meaning) Kehendak hidup bermakna adalah hasrat yang memotivasi setiap orang untuk bekerja, berkarya dan melakukan kegiatan-kegiatan penting lainnya dengan tujuan agar hidupnya berharga dan dihayati secara bermakna. (3) Makna hidup (meaning of life). Makna hidup adalah sesuatu yang dianggap penting, benar dan didambakan seria memberi nilai khusus bagi seseorang. Bila berhasil ditemukan dan dipenuhi akan menyebabkan kehidupan ini dirasakan demikian berarti dan berharga.

Berbeda dengan Frankl, menurut Crumbaugh \& Maholich (Koeswara, 1992) terdapat enam komponen kebermaknaan hid up, yaitu: (1) Makna Hidup. Makna hidup adalah segala sesuatu yang dianggap penting dan berharga bagi seseorang, dan memberi nilal khusus, serta dapat dijadikan sebagai tujuan hidup bagi individu tersebut. (2) Kepuasan hidup. Kepuasan hidup adalah penilaian seseorang terhadap hidup yang dijalaninya, sejauh mana ia mampu menikmati dan merasakan kepuasan dalam hidup dan segala aktivitas yang telah dilakukannya. (3) Kebebasan. Kebebasan adalah perasaan mampu mengendalikan hidupnya secara bertanggung jawab. (4) Sikap terhadap kematian. Sikap terhadap 
kematian adalah pandangan dan kesiapan seseorang terhadap kematian yang dihadapi oleh setiap manusia. (5) Pikiran tentang bunuh diri. Pikiran tentang bunuh diri adalah pemikiran seseorang tentang perbuatan bunuh diri. (6). Kepantasan hidup. Kepantasan hidup adalah penilaian seseorang terhadap hidupnya, sejauh mana ia merasa bahwa apa yang telah ia alami dalam hidup adalah sebagal sesuatu hal yangwajar.

Berdasarkan hasil temuan studi kasus yang dilakukan Bastaman (1996), komponen kebermaknaan hidup dapat dikategorikan dalam empat dimensi, yaitu dimensi personal, sosial, spiritual dan dimensi nilalnilal. Unsur-unsur yang merupakan komponen dimensi personal adalah pemahaman diri dan pengubahan sikap. Dimensi sosial mencakup dukungan sosial, faktor permicu kesadaran diri dan model ideal pengarahan diri. Adapun dimensi nilai-nilai meliputi pencarian makna hidup secara aktifkontemplatif, penemuan makna hidup. keterikatan diri terhadap makna hidup, kegiatan terarah pada tujuan, tantangan dan keberhasilan memenuhi makna hidup. Dari komponen dimensi spiritual adalah keimanan sebagai dasar dari kehidupan beragama.

Selain itu, Battista dan Almond (Wong, 2000) mengindentifikasikan adanya empat pendekatan umum teoritls dalam mengidentifikasi kebermaknaan hidup. Pertama, komitmen secara positif terhadap hal-hal yang berhubungan dengan kebermaknaan hidup, seperti lebih religius dan lebh manusiawi. Kedua, usaha yang kuat dalam mencapai konsep kebermaknaan hidup yang dipegangnya. Ketiga berusaha untuk memenuhi tujuan-tujuan hidupnya. Terakhir adalah terciptanya perasaan berarti dalam hidup.

Dari berbagai komponen kebermaknaan hidup yang dijelaskan di atas, dalam penelitian ini peneliti mensintesiskan komponen kebermaknaan hidup yang dikemukakan Frankl serta Crumbaugh \& Maholick, dan dijadikan dasar dalam membuat skala kebermaknaan hidup. Komponen tersebut terdiri dari: kepuasan hidup, kehendak hidup bermakna, dan kebebasan berkehendak.

Frankl mengemukakan adanya tiga faktor yang dapat mempengaruhi pemenuhan kebermaknaan hidup. Bastaman, (1996) menyebutkan tiga faktor tersebut sebagai sumber-sumber makna hidup, yang terdiri dari: (1) Nilai-nilai kreatif. Nilai-nilai kreatif adalah, bagaimana seseorang mampu memberikan sesuatu yang berharga dan berguna pada kehidupan, melalui komitmen sesungguhnya dalam berkarya. Hal ini terwujud dalam bentuk bekerja, mencipta, dan melaksanakan tugas dalam lingkup yang luas serta dilaksanakan dengan tanggung jawab. Makna diberikan pada setiap momen kehldupan melalui tindakan-tindakan yang menciptakan suatu hasil yang kelihatan, suatu ide atau dapat juga dengan melayani orang lain yang merupakan suatu ungkapan individu. Apa yang dilakukan pun diarahkan agar dirinya dapat berguna bagi dirinya sendiri dan bagi banyak orang. Menjadi bukan persoalan apakah besar atau kecil pekerjaan yang dilakukan, tetapi yang terpenting adalah sikap dan komitmen untuk memberi sesuatu pada kehidupan. (2) Nilal-nilai pengalaman. Nilai-nilai pengalaman merupakan apa yang dlterima oleh individu dari kehidupannya, misal menemukan kebenaran, keindahan dan kasih sayang. Mencoba memahami, meyakini dan menghayati berbagai nilai yang ada dalam kehidupan, seperti kebenaran, keindahan, kaslh sayang, kebajikan, keimanan, dII. Nilai-nilai pengalaman merupakan apa yang diterima oleh individu darl kehidupan melalul interaksinya dengan manusia dan alam. Nilai ini didapat dari Interaksi dan komitmen untuk berhubungan baik dengan orang lain dan lingkungan soslal. (3) Nllai-nilai sikap. Nilai sikap merupakan sikap yang diberikan oleh individu terhadap kondisi-kondisi tragis yang telah terjadi, seperti penyakit, penderitaan dan kematian. Situasi-siluasi yang buruk, yang menimbulkan keputusasaan dan tampak tanpa harapan dapat memberikan kesempatan yang sangat besar bagi individu dalam menemukan makna hidupnya. Dengan mengambil sikap yang tepat, maka 
beban pengalaman-pengalaman tragis itu dapat berkurang, bahkan dapat menimbulkan makna yang lebih berartl. Dari peristiwa terse but dapat mengalir berkah dan pelajaran berharga yang justru membantu proses kematangan dan memberi sumbangan bagi kebaikan di masa mendatang.

Bastaman (1996) menambahkan bahwa faktor-faktor laln yang dapat mempengaruhi kebermaknaan hidup adalah kualitaskualitas insani. Hal tersebut merupakan semua kemampuan, sifat, sikap dan kondisi yang semata-mata terpateri dan terpadu dalam eksistensi manusia dan tidak dimiliki oleh mahluk-mahluk lainnya. Kualitas insani tersebut diantaranya, intelegensia, kesadaran diri, pengembangan diri, humor, hasrat untuk bermakna, moralitas, transendensi diri, kreativitas, kebebasan dan tanggungjawab.

Konsep lain yang dapat menunjang penemuan makna hidup, yang dalam psikologi humanlstik dikenal dengan istilah encounter (Bastaman, 1996). Encounter adalah hubungan mendalam antara seorang pribadi dengan pribadi lain. hubungan ini ditandai dengan penghayatan keakraban dan keterbukaan, serta sikap sallng menghargai, sehingga sindividu dapat memberlkan dukungan dan saling membantu dalam mengatasi kesulitas, dan menuju kearah yang lebih baik.

Berdasarkan pemyataan d atas, dapat diambil kesimpulan bahwa faktor-faktoryang dapat mempengaruhi kebermaknaan hidup adalah nllai-nilai kreatif, nilai-nilai penghayatan, dan nilai-nilai bersikap. Selain itu juga sangat dipengaruhi oleh kualitaskualitas insani dan encounter.

Menurut Franki (Koeswara, 1992) ketika individu gagal memenuhi hidupnya dengan kebermaknaan, maka orang tersebut mengalami sindrom ketidakbermaknaan. Terdapat dua tahapan untuk menandai sindroma ketidakbermaknaan, yakni frustrasi eksistensial dan neurosis noogenic. Frustrasi eksistensial adalah suatu fenomena umum yang berkaitan dengan keterhambatan dan atau kegagalan individu dalam memenuhi keinginan akan makna, sedangkan neurosis noogenik ada|ah suatu manifestasi khusus dari frustrasi eksistensial yang ditandai oleh simptomatologi neurotik klinis tertentu yang terbuka atau tampak.

Frankl (Koeswara, 1992) menyimpulkan bahwa frustrasi adalah suatu fenomena yang semakin banyak ditemui dalam masyarakat modern sekarang Ini. Menurut Frankl (2003) frustrasi eksistensial sejauh tidak disertai dengan gejala-gejala klinis tertentu bukanlah suatu penyakit dalam pengertian klinis, melainkan lebih merupakan suatu penderitaan batin yang berkaitan dengan ketidakmampuan individu untuk menyesuaikan diri dan mengatasi masalah-masalah pribadi dengan baik.

Pemunculan frustrasi eksistensial berkaitan dengan fenomena umum yang dialami oleh manusia saat ini, yaitu manusia tidak lagi memiliki kepastian mengenai apa yang seharusnya dilakukan. Frankl (Koeswara, 1992) mengemukakan bahwa frustrasi eksistensial dapat diketahui melalui beberapa manifestasinya, antara lain: (1) Neurosis kolektif. Neurosis kolektif Ini ditandai dengan ciri-ciri adanya sikap masa bodoh terhadap hidup, slkap pesimls terhadap masa depan, kecenderungan melarikan diri dari tanggung jawab dan menyalahgunakan kebebasannya dan selalu mengingkari kebenaran orang lain. (2) Neurosis pengangguran. Neurosis pengangguran ditunjukkan dengan adanya sikap apatis, tidak acuh dan kehilangan Inislatif. Individu akan mengalaml waktu kosong sebagai kekosongan batin yang pada akhlmya akan mengarah pada kegagalan hidup. (3) Neurosis hari minggu. Neurosis hari minggu adalah bentuk pelarian dalam mengisi kekosongan batin, dan takut akan kematian. Ketakutan akan kematian hanya terjadi pada orang yang tidak memenuhi hidupnya dengan makna. (4) Penyakit eksekutif. Penyakit eksekutif adalah terhambatnya memberi makna pada hldup yang dijalani seseorang yang disebabkan karena kegilaan mencari kekayaan materi. Kesibukan akan materi menyebabkan terlupakannya makna hidupnya sendiri.

Neurosis noogenik adalah suatu manifestasi khusus dari frustrasi eksistensial 
yang ditandai oleh gejala neurotik klinis tertentu yang tampak. Tetapi frustrasi eksistensiaal belum tentu merupakan awal kemunculan suatu penyakit neurosis noogenik. Frankl (Koeswara, 1992) mengemukakan bahwa neurosis noogenik merupakan kategori neurosis yang berakar pad a konflik atau masalah yang muncul pada dimensi noologis atau spiritual yaitu frustrasi eksistensial; yang berbeda dengan neurosis somatogenik (neurosis yang berakar pada kondisi fisiologis tertentu) maupun neurosis kategori psikogenik (neurosis yang bersumber pada konflik-konflik yang muncul pada dimensi psikologis).

Crumbaugh dan Maholick (Koeswara, 1992) mengemukakan bahwa kekurangan makna hidup mengisyaratkan kegagalan individu dalam menemukan pola tujuan dan nilai-nilai yang menyatu dalam hidup yang mengakibatkan terjadinya penumpukan energi. Penumpukan energi inllah yang membuat individu menjadi lemah serta kehilangan semangat untuk berjuang mengatas| berbagal hambatan, termasuk hambatan dalam mencari makna.

Keinglnan akan makna tetap ada dan bekerja pada individu yang mengalami frustrasi eksistensial, akan tetapi karena individu tidak memiliki pola atau kerangka acuan yang terorganisasi yang dibutuhkan. Sebagai titik tolak pencapaian makna, keinginan individu untuk mencapai makna tersebut tidak bisa terwujud sehingga tekanan yang ditimbulkan oleh frustrasi eksistensialnya semakin kuat. Peningkatan tekanan ini menyebabkan individu terus menerus berada dalam pencarian cara-cara yang dharapkan bisa menjadl saluran bagi pengurangan tekanan tersebut.

Cara termudah yang sering dilpilih seseorang untuk mengurangi tekanan yang ditimbulkan frustrasi eksistensial adalah menghanyutkan diri ke dalam arus pengalaman kompensatori dan menyesatkan, antara lain minumanminuman keras, obat bius, bermainjudi, atau melakukan petualangan seksual. Kekurangan akan makna merupakan kondisi yang bisa dikuti oleh kegagalan penyesuaian terhadap berbagai masalah seperti depresi yang semakin banyak dialami oleh masyarakat modern saat ini. Studi Edward dan Helden (Twenge dkk, 2003) menemukan fakta bahwa ketidakbermaknaan hidup memunculkan tendensi untuk bunuh diri. Mereka menganggap hidup adalah suatu hal yang tidak berarti sehingga bunuh dri adalahjalan keluar dari persoalan tersebut.

\section{Motif Sosial}

Cofer dan Apply (1964) beranggapan bahwa apa yang disebut dengan motif sosial adalah aspek-aspek motif yang diperoleh dari faktor situasional atau eksternal. Lindgren (1973) beranggapan bahwa motif sosial adalah motif yang dipelajari dan bahwa lingkungan individu memegang peranan penting. Motif sosial Ini dipelajari melalui kontak dengan orang lain. Juga Teevan den Smith (1964) beranggapan bahwa motif sosial dipelajari melalui interaksi interpersonal. Heckhausen berpendapat bahwa motif sosial adalah motif yang menunjukkan bahwa tujuan yang ingin dicapal mempunyai interaksi dengan orang lain.

Atas dasar pendapat-pendapat tersebut, definisl motif sosial adalah motif yang dipelajarl melalui interaksi interpersonal dan tujuan yang ingin dicapainya adalah mempunyai interaksi dengan orang lain. Menurut McClelland (1987), motif sosial antara lain: motif berprestasi (achiovement motive), motif berafiliasi (affiliation motive) dan motif berkuasa (power motive).

Motif berprestasi adalah motif yang mendorong Individu mencapai sukses untuk dapat berhasil dalam kompetisi dengan suatu ukuran keunggulan. Ukuran keunggulan dapat berupa prestasi orang lain, prestasi diri sendiri dan dapat pula kesempurnaan tugas. Menurut McCleliand (1987) individu dengan kebutuhan berprestasi tinggi menampilkan perilaku antara lain: pertama, lebih menyukai tugas yang menantang dengan tingkat kesulitan yang moderat. Kedua, meyukal adanya umpan balik terhadap sejauh mana keberhasilan yang dicapai dalam 
menyelesaikan suatu pekerjaan. Ketiga, dinamis dan memiliki mobilitas tinggi dalam melaksanakan pekerjaan. Keempat, cenderung meningkatkan wawasan dalam bekerja sehingga akan terus mampu mengerjakan pekerjaan yang menantang dan sulit. Kelima, dalam bekerja mengetahui apa yang harus dikerjakan untuk mencapal has i yang telah ditetapkan. Motif berprestasi ini dipengaruhi oleh beberapa faktor seperti lingkungan, norma kelompok, tujuan, harapan, kedisiplinan, pengalaman, potensi dasardan dorongan sukses.

Motif berafiliasi adalah motif yang mendorong, mengarahkan tingkah laku seseorang untuk berinteraksi dengan orang lain, yang mengandung unsur kepercayaan, afeksi dan kebersamaan. Menurut McCleiland (1987), motif berafiliasi merupakan kebutuhan akan kehangatan dan dukungan dalam hubungannya dengan orang lain. Motif inilah yang mendorong individu untuk berhubungan sosial, seperti bergaul, bekerjasama, dihargai, diakui secara sosial dan masuk dalam kelompok. Orang yang memiliki matif berafiliasi tinggi mempunyai ciri-ciri yaitu selalu ingin berhubungan dengan orang lain, konformis, mempunyai kebutuhan bekerjasama, keinginan memberi maaf kepada orang lain, rasa empati kepada orang lain dan memiliki keinginan untuk menyenangkan oran lain. Motif berafiliasi ini dipengaruhi oleh situasi lingkungan dan juga faktor psikologis seperti dorangan deindividuasi, keraguan, keadaan tertekan dan perasaan kesamaan.

Motif berkuasa adalah motif yang mendorong individu untuk menguasai atau mendominasi orang lain. Menurut McClelland (1987), motif berkuasa adalah hasrat seseorang untuk mengendalikan atau mempengaruhi orang iain yang lebih rendah. Orang yang memiliki motif berkuasa tinggi leb!h menaruh perhatian pada prestise daripada prestasi. Mereka cenderung mengontral dan mendominasi orang lain. Motif berkuasa yang tinggi pada dri seorang individu, cenderung membuatnya mencari kedudukan yang mempunyai kekuasaan. Sebaiknya orang yang memiliki motif berkuasa rendah cenderung meninggaikan pekerjaan yang memiliki kekuasaan.Orang yang memiliki motff berkuasa tinggi memiliki ciri-ciri, adanya kebutuhan untuk berkuasa, keadaan afektif dalam menguasai atau mempengaruhi orang lain. memperhitungkan rintangan yang ada, mengantrol orang lain, harapan akan tujuan berkuasa dan mempunyai keinginan untuk prestise. Matif berkuasa muncul karena pengaruh kebudayaan dan faktor individual, selain itu dipengaruhi pula oleh kesempatan dan norma yang ada dalam masyarakat.

Motif Sosial dan Kebermaknaan Hidup

Menurut Frankl (Bastaman, 1996) terdapat beberapa faktor yang dapat mempengaruhi pemenuhan kebermaknaan hidup. Di antaranya adalah nilai-nilai kreatif. Niiai-nilai kreatif adaiah bagaimana seseorang mampu memberikan sesuatu yang berguna bagi kehidupan, melalui komitmen sesunguhnya dalam berkarya. Hal ini terwujud dalam bentuk bekerja, mencipta, berkreasi, berprestasi. Nilai-nilai kreatif terkait dengan motif berpreslasi. Ketika seorang individu berkarya, bekerja, berprestasi berarti pribadi tersebut telah memberikan sesuatu kepada kehidupan, Pribadi tersebut juga dapat menemukan keunikan dirinya serta menemukan hal-hai menarik yang menambah pengalaman hidup. Hal tersebut menjadi sumber kepuasan dan kesenangan dalam hidup, yang pada akhimya berpengaruh terhadap kebermaknaan hidup. Sahakian (Baslaman, 1996) menyalakan bahwa kebahagiaan tidak mungkin diraih tanpa melakukan perbualanperbuatan penting dan bermanfaat. Hal ini didukung oleh Wong dan Fry (1998) serta Adler (2004) yang menyatakan bahwa bekerja atau berprestasi adalah salah satu sumber kebermaknaan hldup.

Selanjutnya, faktor yang mempengaruhi kebermaknaan hidup adalah nilai-nilal pengalaman. Nilai-nilai pengalaman merupakan apa yang diterima oleh individu dari kehidupan melalui interaksi dengan orang lain, yakni menemukan kebenaran, keindahan, cinla dan kasih sayang. Hal ini terkait dengan motif berafiliasi, yakni motif 
yang mendorong, mengarahkan tingkah laku seseorang untuk berinteraksi dengan orang lain, yang mengandung unsur kepercayaan, afeksi dan kebersamaan. Hubungan yang baik dengan orang lain akan membuat seseorang merasakan keakraban, kepercayaan, afeksi, dukungan, kebersamaan sehingga dapat menimbulkan rasa bahagia, kepuasaan, ketentraman dan perasaan diri bermakna. individu yang memiliki motif berafiliasi tinggi akan memungkinkannya mencapai kebermaknaan hidup yang tinggi pula. Lebih dalam, Adier (2004) berkesimpulan bahwa orang yang gagal memaknai hidupnya disebabkan karena minimnya rasa untuk berteman dan kurangnya perhatian sosial.

Frank (2003) juga menyebutkan, ketika seseorang menjadikan kekuasaan sebagai tujuan, maka hal tersebut akan sangat merusak dirinya. Pemujaan pada aspek material, menjadikan diri sebagai pusat dan mengesampingkan pelayanan serta kebersamaannya dengan orang lain sesungguhnya akan mereduksi pemahaman seseorang akan eksistensi dirinya. Kekuasaan yang dimaksud Frankl terkait dengan motif kekuasaan, yakni motif yang mendorong individu untuk menguasai atau mendominasi orang lain.

Motif berprestasi, motif berafiliasi, dan motif berkuasa termasuk motif sosial. Menjadi relevan kemudian jika menghubungkan ketiga motif sosial tersebut dengan kebermaknaan hidup. Selain itu, faktor internal yang disebut motif yang ada dalam diri manusia dapat menimbuikan, mengarahkan dan mengintegrasikan perilaku, sehingga motif sosial dalam diri individu dapat berpengaruh pada bagaimana kebermaknaan hidup seseorang. Seperti yang dikemukakan Walgito (2004), sikap sesungguhnya mengandung motif tertentu yang mempunyai daya dorong untuk berperilaku. Motif memberikan arah pada perilaku untuk menuju suatu tujuan.

\section{Hipotesis}

Berdasarkan uraian yang telah dikemukakan sebelumnya, maka hipotesis yang diajukan dalam penelitian ini adalah: motif berprestasi, motif berafliasi, motif berkuasa memiliki hubungan dengan kebermaknaan hidup pada remaja Pagaralam. Motif berprestasi dan motif berafiliasi berperan positif terhadap kebermaknaan hidup, sedangkan motif berkuasa berperan negatif terhadap kebermaknaan hidup pada remaja Pagaralam.

\section{Metode Penelitian}

Penelitian ini menggunakan tiga variabel bebas, yakni motif berprestasi, motif berafiliasi, molif berkuasa, serta satu variabel tergantung, yakni kebermaknaan hidup.

Penelitian dilakukan di Kota Pagaralam, Sumatera-Selatan. Partisipan adalah remaja dari beberapa SMU, yakni SMU Negeri 1 , SMU Negeri 2, SMU Muhammadiyah. Metode sampling yang digunakan adalah purposive sampling. Jumlah partisipan dalam penelitian ini adalah 171 orang, terdiri dari 77 laki-laki dan 94 perempuan, dengan ciri-ciri sebagai berikut: (a) remaja Kota Pagaralam, (b) laki-laki dan perempuan, (c) berumur 15 21 tahun.

Kebermaknaan hidup adalah penghayatan remaja mengenai kualitas, tujuan dan harapan dalam hidupnya agar dapat berarti bagi diri sendiri dan sesama. Pengukuran kebermaknaan hidup ini diungkap dengan skala kebermaknaan hidup yang disusun oleh penulis. Skala ini merupakan sintesa dari komponen kebermaknaan hidup yang dikemukakan Frankl (Bastaman, 1996) serta Crumbaugh \& Maholick (Koeswara, 1992). Skala ini terdiri dari tiga aspek, yakni: kepuasan hidup, kehendak hidup bermakna, kebebasan berkehendak.

Ketiga motif sosial akan diukur dengan menggunakan skala motif sosial yang dibuat oleh peneliti dengan menggunakan aspekaspe $k$ yang dimodifikasi dari sistem pengukuran TAT versi McClelland. Skala tersebut terdiri dari sembilan elemen. Kesembilan elemen tersebut adalah: kebutuhan, usaha, harapan akan hasil, harapan akan kegagalan, rintangan intemal, rintangan eksternal, tekanan yang mendidik, keadaan afektif positif, keadaan afektif negatif. 


\section{Hasil Penelitian}

Dari hasil analisis regresi ganda diperoleh $F$ hitung $=29,983$ dengan taraf signifikansi $p=0,000$. Hal ini menunjukkan bahwa motif berprestasi, motif berafiliasi dan motif berkuasa memiliki pengaruh yang signifikan terhadap kebermaknaan hidup pada remaja Pagaralam. Dengan demikian hipotesis tersebut diterima.

Ditemukan pula koefisien determinasi $\left(R^{2)}\right.$ sebesar 0,350 yang berarti bahwa sekitar $35 \%$ sumbangan motif berprestasi, motif berafiliasi dan motif berkuasa terhadap variabel kebermaknaan hidup, sedangkan sisanya sebesar $65 \%$ dijelaskan oleh prediktor lain dan kesalahan-kesalahan lain (erorsampling dan non sampling).

Terdapat pengaruh positif dan signifikan antara motif berprestasi dengan kebermaknaan hidup. Semakin tinggi motif berprestasi maka semakin tInggi kebermaknaan hldupnya demikian sebaliknya.Dengan perhitungan konversi didapat pula sumbangan motif berprestasl terhadap kebermaknaan hidup sebesar $20,1 \%$.

Terdapat pengaruh positif dan signifikan antara motif berafiliasi dengan kebermaknaan hidup. Semakin tinggi motif berafiliasi maka semakin tinggi pula kebermaknaan hidupnya, demlkian sebaliknya. Dengan perhitungan konversi didapat pula sumbangan motif berafiliasi tehadap kebermaknaan hidup sebesar $9,15 \%$.

Terdapat pengaruh negatif dan signifikan antara motif berkuasa dengan kebermaknaan hidup. Semakin tinggi motif berkuasa maka semakin rendah kebermaknaan hidup, demikian sebaliknya. Dengan perhitungan konversi didapat pula sumbangan motif berkuasa terhadap kebermaknaan hidup sebesar $5,75 \%$.

\section{Pembahasan}

Hasil analisis data menunjukkan peran yang signlfikan antara motif berprestasi, motif berafiliasi dan motif berkuasa dengan kebermaknaan hidup, dengan sumbangan sebesar $35 \%$. Hal ini berarti, sekitar $35 \%$ sumbangan ketiga prediktor yaitu motif berprestasi, motif berafiliasi, motif berkuasa terhadap variabel kebermaknaan hidup, sedangkan $65 \%$ dijelaskan oleh faktor-faktor lain dan kesalahan-kesalahan lain (error sampling dan non sampling). Seperti dikemukakan Franki (2003), selain nilai-nilai kreatif dan nilai-nilai pengaiaman, kebermaknaan hidup juga dipengaruhi oleh nilai-nllai sikap, yakni sikap yang positif ketika menghadapi penderitaan dan tantangan-tantangan hidup. Ditambahkan pula oleh Bastaman (1996) bahwa kebermaknaan hidup seseorang sangat dipengaruhi oleh kualitas-kualitas insani (transendensl diri, humor, tanggung jawab, kesadaran dirl, moralitas, dll) dan encounter.

Hasil analisis menunjukkan pula tingkat kebermaknaan hidup remaja Kota Pagaralam termasuk kategori tinggi. Hal ini menunjukkan bahwa penghayatan remaja Pagaralam mengenai kualitas, tujuan dan harapan hidupnya agar dapat berarti bagi điri sendiri dan sesama, adalah tinggi.

Hasil analisis juga menunjukkan edanya pengaruh yang signifikan antara motif berprestasi dengan kebermaknaan hidup. Sumbangan motif berprestasi juga cukup tinggi dibandingkan variabei laín, yakni $20,1 \%$. Hasil ini mendukung kesimpulan Frankl (Bastaman, 1996), yang mengungkapkan bahwa nilai-nilai kreatif dapat mempengaruhi pemenuhan kebermaknaan hidup. Ketka seorang individu berkarya, bekerja, berprestasi berarti pribadi tersebut telah memberikan sesuatu kepada kehldupan. Hal tersebut menjadi sumber kepuasan dan kesenangan dalam hidup, yang pada akhimya akan berpengaruh terhadap kebermaknaan hidupnya. Seperti yang dikemukakan Sahakian (Bastaman, 1996) menyatakan bahwa kebahagiaan tidak mungkin diraih tanpa melakukan perbuatan-perbuatan penting dan bermanfaat.

Temuan ini juga menegaskan kembali kesimpulan Wong dan Fry (1998) sertaAdler (2004) yang menyatakan bahwa bekerja atau 
berprestasi adalah salah satu sumber kebermaknaan hidup. Besarnya peran berprestasi dalam kebermaknaan hidup juga pernah dibuktikan oleh penelitlan Bastaman (1996). Orang-orang yang mengalami hidup tidak bermakna setelah melakukan perubahan dengan melakukan pekerjaan positif dan pengembangan potensi dirl (directed activities) mereka merasakan perubahan pada kondiși kehidupan yang lebih bermakna.

Analisis deskriptif menunjukkan bahwa tlngkat motif berprestasi remaja Pagaralam termasuk tinggi. Tingginya motif berprestasi bisa disebabkan karena tingkat pendidikan orang tua saat ini relatif cukup tinggi (BPS, 2003), sehingga mereka mendukung dan memotivas| anak-anak mereka untuk berprestasi. Sebagaimana dikemukakan Atkinson dkk (1964) bahwa motif berprestasi dipengaruhi oleh dorongan untuk sukses, kemungkinan untuk sukses dan nilai tambah sukses. Di sisi lain, tIngginya motif berprestasi ini adalah akibat dari pendidikan dini untuk berdiri sendiri dan menguasai kecakapan-kecakapan (McCleland, 1967) dan didukung pula oleh Haditono (Martaniah, 1984), bahwa cara orang tua mendidik anak akan mempengaruhi motif berprestasi anak. Menurut pengamatan penulis, remaja di Kota Pagaralam, mulal dari anak-anak sudah diberi banyak tanggung jawab dan dilath mandiri.

Hasil analis|s juga menunjukkan adanya pengaruh positif dan signifikan antara motif berafiliasl dengan kebermaknaan hidup. Sumbangan motif berafiliasi sebesar $9,15 \%$. Hasil ini mendukung pandangan Frankl (Bastaman, 1996) bahwa pemenuhan kebermaknaan hidup dipengaruhi oieh nllainilai pengalaman. Hubungan baik dengan orang lain akan membuat seseorang merasakan keakraban, kepercayaan, af eksi, kebersamaan sehingga dapat menimbulkan rasa bahagia, kepuasaan, ketentraman dan perasaan dirl bermakna. Dengan interaksi dan cinta yang dirasakan dengan orang lain seseorang akan mengalami pemerkayaan batin, sehlngga akan meningkatkan kebermaknaan hidup.

Temuan ini selaras dengan kesimpulan
Wong dan Fry (1998), yang mengungkapkan bahwa hubungan yang baik dengan orang iain merupakan aspek penting mencapai kebermaknaan hidup. Dengan interaksi dan cinta yang dirasakan dengan orang lain seseorang akan mengalami pemerkayaan batin. Lebih dalam, Adler (2004) berkesimpulan bahwa orang yang gagal memaknai hidupnya disebabkan minimnya rasa untuk berteman dan kurangnya perhatian sosial.

Tingginya motif berafiliasi pada remaja Pagaralam, bisa disebabkan budaya orang Pagaralam dan Sumatera Selatan pada umumnya memiliki tradisi saling menolong dan rasa kebersamaan yang tinggi (Depdikbud, 1984). Salah satunya terlihat dari terlibatnya warga kampung dalam mempersiapkan pesta pernikahan atau sedekah. Masyarakat Pagaralam juga selalu aktif dalam mengikuti kegiatan-kegiatan sosial kemasyarakatan, yang cukup banyak. Kebutuhan untuk berlnteraksi dan membutuhkan orang lain tersebut juga terllhat dari perllaku keseharlan masyarakatnya, yang tentu saja kemudian diinternalisasi dan diterapkan kaum remajanya.

Hasil analisis juga menunjukkan adanya pengaruh negatif dan signifikan antara motif berkuasa dengan kebermaknaan hidup. Sumbangan motif berkuasa sebesar $5,75 \%$. Hasil ini mendukung apa yang dikemukakan Frankl (Koeswara, 1992), meski perannya bisa dikatakan kecil. Motif berkuasa adalah motif yang mendorong individu untuk menguasai atau mendominasi orang lain. Orang yang memiliki motif berkuasa tinggi memiliki ciri-ciri, yaitu adanya kebutuhan untuk berkuasa, aktivitas berupa perbuatan atau pikiran untuk mengontrol orang lain, harapan akan tujuan berkuasa dan mempunyai keinginan untuk prestise. $\mathrm{Hal}$ ini menunjukkan hubungannya dengan orang lain semata-mata untuk keuntungan diri sendiri. Orientasi utama pada kekuasaan adalah kelnginan mendapatkan kesenangan dan ini bertentangan dengan prinsip kebermaknaan hidup. Frankl juga menyebutkan jika seseorang menjadikan kekuasaan sebagal tujuan, maka hal 
tersebut akan sangat merusak dirinya. Individu tersebut akan semakin sulit menemukan kebahaglaan dan kebermaknaan dalam hidupnya. Pemujaan pada aspek material, menjadikan diri sebagai pusat dan mengesampingkan pelayanan serta kebersamaan dengan orang lain sesungguhnya akan mereduksi pemahaman akan eksistensi diri. Hal hi didukung pendapat Madjid (Bastaman, 1996) yang berpandangan bahwa tekanan yang berlebihan pada segi material kehidupan, akan mengakibatkan hilangnya kesadaran akan makna hidup yang mendalam

Analisis deskriptif menunjukkan bahwa tingkat motif berkuasa remaja Pagaralam adalah sedang. Hal bisa disebabkan dinamika masyarakatnya yang tidak terialu kompleks seperti di kota besar. Seperti dikemukakan Martaniah (1984) bahwa motif berkuasa muncul disebabkan ketidakpastian dan kecemasan. Remaja Pagaralam hidup dalam dinamika budaya agraris dengan suasana kooperatif dan tidak kompleks seperti kota besar yang sangat menjunjung tinggi aspirasi materl, persaingan, efektiktivitas dan efisiensi.

Sebagai catatan akhir, membicarakan teori Fankl tentang kebermaknaan hidup dan dihubungkan dengan kondisi kehidupan sekarang ini memang terkesan kurang realistis. Terutama jika diterapkan bagi kehidupan remaja. Teori ini berpijak dan muncul dari jaman, aliran dan situasi yang jauh berbeda dengan kondisi sekarang. Seperti yang dikemukakan Santrock (2003) bahwa remaja sekarang lebih banyak menjadikan kemapanan secara finansial dan materi sebagai hal utama dibandingkan mengembangkan filosofi hidup.

Meskipun demikian, membincang soal kebermaknaan hidup sesungguhnya sangatlah penting. Tentunya dengan konsep yang bisa diselaraskan dengan situasi sekarang. Efektivitas dan efisiensi yang dijunjung tinggi di jaman modem ini telah mengasingkan manusia dari dirinya sendiri dan lingkungan sosial. Penting kemudian melakukan upaya agar manusia melakukan otokritik terhadap eksistensi diri dan kemanusiaannya, apalagi kebermaknaan hidup sangat terkait dengan kesehatan dan kualitas keberadaan manusia.

Remaja sebagai fase yang akan menentukan kehidupan fase berikutnya penting pula untuk memahami. Hal mendasar dari kebermaknaan hidup adalah hasrat atau komitmen untuk berarti bagi diri sendiri dan lingkungan. Siapapun, bahkan remaja sangat penting untuk memiliki komitmen tersebut. Selain itu, sebagaimana dikemukakan Bastaman (1996) bahwa kebermaknaan hidup tidak selalu berkaitan dengan hal-hal rumit dan filosofis. Melakukan hal-hal sederhana yang ditujukan agar dirinya dapat berguna bagi dirinya sendiri dan bagi banyak orang, merupakan langkah besardalam meraih kebermaknaan hid up

\section{Penutup}

Hasil penelitian menunjukkan adanya hubungan antara motif berprestasi, motif berafiliasi dan motif berkuasa dengan kebermaknaan hidup pada remaja Pagaralam. Hasil tersebut dapat menjad saran kepada semua pihak, baik itu pemerintah, sekolah, orang tua, remaja, masyarakat luas agar melakukan berbagai usaha untuk memaksimalkan aspek-aspek yang berpengaruh positif terhadap kebermaknaan hidup dan meminimalisasi aspek-aspek yang kontraproduktif bagi perkembangan kebermaknaan hidup remaja. Di antaranya menggalakkan kegiatan ekstrakulikuler di sekolah, pemberian beasiswa kepada remaja berprestasi, mendirikan berbagai ruang publik, gelanggang atau sentra-sentra kegiatan bagi perkembangan kreativitas dan mengembangkan kemampuan sosial remaja.

\section{Daftar Pustaka}

Adelson, J. 1980. Handbook of Adolescence Psychology. New York John Willey \& Sons

Adler, A 2004. What Life Should Maan to You Jadikan Hidup Lebih Bermakna. Yogyakarta: Alenia. 
Bastaman, H.D. 1996. Meraih Hidup Bermakna. Jakarta: Paramadina

Coffer, C.N \&Appley, M.H. 1964. Motivation: Theory and Research. New York: Willey and Sons.

Conger, J.J. 1977. Adolescence and Youth. Psychological Development in A Changing World. New York : Harper \& Row.

Damon, W. Menon, J \& Bronk, K. 2003. The Developmental Of Purpose During Adolescence. Joumal of Applied Developmented Science. Vol 7 . Number 3, 119-128.

Debats, D.L. 1999, Sources Of Meaning: an Investigation of Signifikan Commitment In Life. Journal or Humanistik Psychology. Vol 39, Number4,387-390.

Frankl, V.E., 2003. Man's Search For Meaning; an introduction to Logotherapy. Edisi Terjemahan. Yogyakarta: Kreasi Wacana.

Fromm, E. 2002. The Aut of Loving. Edisi bahasa indonesia. Jakarta: Fresh Book

Fuhrmann. 1990. Adolescence, Adolescence. London: Foreman \& Company

Koeswara, E. 1992. Logoterapi Psikoterapi Victor Frankl. Yogyakarta: Kanisius

Koentjoro. 1997. Understanding Prostitution From Rural Communities of Indonesia. Thesis. Victoria-Australia: Departement of Social Work and Social Poltey, School of Public Health-Faculty of Health Sciences, La Trobe University.

Leath, C. 1999. The Experience Of meaning In Life From Psychological Perspective. www experienceart.org.

Lindgren, H.C. 1973. An Introduction To Social Psychology. New Delhi: Willey
Martaniah, S.M. 1984. Motif Sosial Remaja Suku jawa dan Keturunan Cina. Disertasi. Yogyakarta: Program Studi Psikologi Universitas Gadjah Mada

McClelland, David C. 1961. The Achioving Society. New York: D. Van Nostrand Company inc.

1987. Human Molivation. New $\bar{Y}$ : ak Cambridge University Press.

Murray, E.J. 1964. Motivation and Emotion. New Jersey: Prentice Hall

Okamoto, H. 1990. An Existential Tendency For Life and Family Satisfaction in Modem College Student. Javanese Journal of Family Psychology, 4, 2, 83-95.

Santrock, J.W. 2003. Adolescence. Perkembangan Remaja. Edisi Terjemahan. Jakarta: Erlangga.

Sarwono, S.W. 1981. Pergeseran Norma Perilaku Seksual Kaum Remaja. Jakarta: CV. Rajawali.

Schultz, D. 1991. Psikologi Pertumbuhan. Edisi Terjemahan. Yogyakarta: Kanisius

Setiyartomo, PW. 2004. Succesfull Aging Ditinjau dari Kebermaknaan Hidup dan Orientasi Religius Pada Lansia. Tesis. Yogyakarta: Program Studi Psikologi Universitas Gadjah Mada

Teevan R.C. \& Smith, B.D. 1967. Motivation. New York: McGraw Hill

Twenge, J,M., Catanesse, KR \& Baumester, R.F. 2003. Social Exclusion and The Deconstructed State: Time Perception, Meaninglessness. lethargy, Lack Of Emotion and Self Awareness. Journal of Personality and Social Psychology. Vol 85. Number 3. 409-423.

Wong, P.T.P. 2000. Meaning of Life And Meaning of Death in succesfull Aging. Dalam wwwmeaning.ca. 